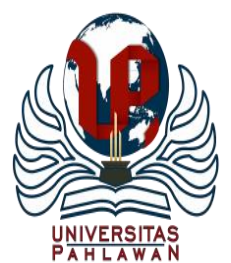

Edukatif : Jurnal Ilmu Pendidikan Volume 3 Nomor 3 Tahun 2021 Halm 854 - 864 EDUKATIF: JURNAL ILMU PENDIDIKAN

Research \& Learning in Education

https://edukatif.org/index.php/edukatif/index

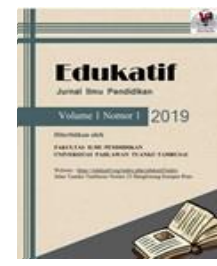

\title{
Apakah Penerapan Blanded Learning Dapat Meningkatkan Motivasi dan Hasil Belajar Siswa dalam Pembelajaran Jarak Jauh?
}

\author{
Lidya Angie Widyasari $^{1 凶}$, Mohamad Arief Rafsanjani ${ }^{2}$ \\ Universitas Negeri Surabaya, Indonesia ${ }^{1,2}$ \\ E-mail : $\underline{\text { lidya.17080554003@mhs.unesa.ac.id }}{ }^{1}, \underline{\text { mohamadrafsanjani@unesa.ac.id }}^{2}$
}

\begin{abstract}
Abstrak
Pelaksanaan penelitian ini memiliki tujuan untuk menganalisa pengaruh penerapan blended learning berbasis sinkron dan asinkron pada materi inflasi, kebijakan moneter, dan kebijakan fiskal sebagai upaya meningkatkan motivasi dan hasil belajar ekonomi peserta didik SMAN 1 Puri Mojokerto dalam pembelajaran jarak jauh. Penelitian ini merupakan jenis penelitian eksperimen semu dengan bentuk desainnya yaitu post-test only control group design. Penelitian ini melibatkan 30 siswa dengan kelas XI IPS 3 sebagai kelompok eksperimen dan kelas XI IPS 2 sebagai kelompok kontrol. Instrumen penelitian menggunakan kuesioner untuk mengetahui motivasi belajar dan soal posttest untuk mengukur hasil belajar ekonomi. Berdasarkan temuan analisis data yang diuji dengan independent sample t-test diperoleh hasil penelitian bahwa terdapat perbedaan motivasi dan hasil belajar yang signifikan antara kelas eksperimen dan kelas kontrol. Dengan demikian dapat disimpulkan bahwa motivasi dan hasil belajar ekonomi peserta didik dapat mengalami peningkatan dengan diterapkannya blended learning berbasis sinkron dan asinkron dalam pembelajaran jarak jauh.
\end{abstract}

Kata Kunci: blended learning, motivasi belajar, hasil belajar.

\begin{abstract}
The implementation of this research to find out the impact of synchronous and asynchronous based blended learning on inflation, monetary policy, and fiscal policy as an effort to increasing motivation and learning outcomes of economics along with the students of SMAN 1 Puri Mojokerto in distance learning. This research is a quasi-experimental research type with a post-test only control group design. The research involved 30 students with XI IPS 3 as the experimental group and XI IPS 2 as the control group. The research instrument use a questionnaire to determine learning motivation and posttest to measure learning outcomes of economics. Based on the findings of the data analysis processed with the independent sample t-test, it obtained show that there are significant differences in learning motivation economic learning outcomes between the experimental group and the control group. Thus it can be inferenced that the motivation and economic learning outcomes of students can increase with the implementation of synchronous and asynchronous based blended learning in distance learning.
\end{abstract}

Keywords: blended learning, learning motivation, learning outcomes.

Copyright (c) 2021 Lidya Angie Widyasari, Mohamad Arief Rafsanjani

$\triangle$ Corresponding author

Email : lidya.17080554003@mhs.unesa.ac.id

DOI : https://doi.org/10.31004/edukatif.v3i3.453

ISSN 2656-8063 (Media Cetak)

ISSN 2656-8071 (Media Online)

Edukatif : Jurnal Ilmu Pendidikan Vol 3 No 3 Tahun 2021 p-ISSN 2656-8063 e-ISSN 2656-8071 


\section{PENDAHULUAN}

Pandemi covid-19 menimbulkan berbagai dampak yang cukup substansial dalam berbagai elemen kehidupan sehingga menjadikan pemerintah harus segera cepat dan tanggap dalam menciptakan perubahan serta pembaharuan strategi atau kebijakan yang bisa diterapkan tepat sasaran. Kebijakan yang dikeluarkan pemerintah yaitu menghimbau kepada seluruh masyarakat untuk menjaga jarak antar satu dengan yang lainnya atau physical distancing. Oleh karenanya, segala kegiatan atau aktivitas di luar rumah perlu diberhentikan terlebih dahulu dan diganti dengan stay at home guna mengurangi risiko masyarakat untuk berkumpul dan berkerumun dengan banyak orang.

Ranah pendidikan pun turut merasakan adanya perubahan kebijakan yang mana imbas dari adanya pandemi covid-19. Melalui Surat Edaran Mendikbud RI No 4 Tahun 2020 (Kemendikbud, 2020) tentang Pelaksanaan Kebijakan Pendidikan Dalam Masa Darurat Penyebaran Covid-19, Mendikbud menghimbau kepada seluruh jenjang sekolah, perguruan tinggi, dan lembaga pendidikan lainnya bahwa aktivitas belajar mengajar berlangsung secara daring dari rumah masing-masing, sehingga proses pembelajaran secara tatap muka langsung di sekolah ditiadakan untuk sementara waktu. Hal ini dimaksudkan guna mengurangi dan menurunkan meluasnya angka persebaran covid-19, maka segala aktivitas yang dapat memicu kerumunan dan perkumpulan yang dapat melibatkan banyak orang perlu dihindari. Kegiatan belajar yang awalnya dilakukan secara konvensional, perlu mengikuti kebijakan baru yang telah diubah oleh Mendikbud yakni dengan melaksanakan Pembelajaran Jarak Jauh (PJJ) dimana proses belajar mengajar 100\% melalui online tanpa ada tatap muka (Maulida, 2020).

Kualitas pembelajaran menjadi dampak yang ditimbulkan dengan kondisi seperti ini, dimana guru dan peserta didik yang awalnya dapat berkomunikasi dan interaksi secara langsung dalam kelas namun saat ini interaksi yang dilakukan menjadi terbatas hanya dalam ruang virtual. Dengan dihadapkan pada kondisi yang terjadi saat ini, maka guru harus mampu mengembangkan proses pembelajaran dengan efektif agar tidak mengakibatkan pada penurunan kualitas belajar peserta didik. Pada aspek pendidikan, motivasi menjadi tahap awal yang sangat dibutuhkan dalam belajar guna memberikan dorongan untuk bisa bersemangat mempelajari sesuatu (Manggabarani et al., 2016). Revolusi dalam pembelajaran diperlukan agar guru mampu memberikan proses belajar yang optimal serta menumbuhkan motivasi belajar peserta didik untuk mewujudkan tujuan yang akan dicapai (Kholifah \& Buditjahjanto, 2016). Proses pembelajaran yang menarik dengan memanfaatkan perkembangan teknologi diperlukan guru untuk menumbuhkan motivasi belajar peserta didik. Oleh karenanya, dalam kondisi seperti ini guru harus mampu mengemas pembelajaran yang efektif dan tetap mengedepankan kualitas pembelajaran sehingga dapat membangkitkan antusiasme peserta didik dalam belajar dan berhasil memperoleh hasil belajar yang maksimal.

Adanya motivasi belajar yang tinggi akan mampu mendorong keberhasilan peserta didik dalam belajar yang ditandai dengan hasil belajar yang tinggi pula (Kholifah \& Buditjahjanto, 2016). Kondisi yang ditemui peneliti sebagai hasil wawancara di SMA Negeri 1 Puri Mojokerto dengan guru mata pelajaran ekonomi, bahwa cukup banyak nilai peserta didik yang belum mencapai 78 sebagai KBM (Ketuntasan Belajar Minimal). Selain masih rendahnya ketuntasan belajar, motivasi belajar peserta didik juga menurun selama pembelajaran daring, hal ini terlihat dari kurangnya partisipasi dan keaktifan dalam pembelajaran. Saat pengumpulan tugas pun tidak tepat waktu, masih ditemukan sebagian peserta didik yang tidak mengumpulkan, peserta didik seperti kurang bersemangat dan kurang memperhatikan kegiatan pembelajaran. Peserta didik cenderung pasif dalam berpendapat, bertanya, maupun menjawab, terlebih lagi cara guru melakukan proses belajar mengajar yakni dengan mengirimkan materi yang setelahnya diberikan tugas. Guru tidak memberikan penjelasan dari materi yang dikirim kepada peserta didik, sehingga mengurangi interaksi dan komunikasi antara pengajar dan peserta didik selama kegiatan pembelajaran menjadikan suasana belajar menjadi pasif. Guru mata pelajaran ekonomi juga mengungkapkan bahwa selama pembelajaran daring 
856 Apakah Penerapan Blanded Learning Dapat Meningkatkan Motivasi dan Hasil Belajar Siswa dalam Pembelajaran Jarak Jauh? - Lidya Angie Widyasari, Mohamad Arief Rafsanjani

DOI: https://doi.org/10.31004/edukatif.v3i3.453

diberlakukan berpengaruh pada motivasi belajar siswa, dimana siswa mengalami penurunan motivasi dalam belajar selama situasi pandemi ini yang mana mempengaruhi pula pada penurunan hasil belajarnya.

Mengingat begitu pentingnya proses pembelajaran, pemanfaatan teknologi yang ada dapat dilakukan untuk mengatasi permasalahan ini. Perkembangan teknologi masa kini, bisa dipergunakan oleh guru guna menciptakan media, strategi, dan model pembelajaran yang variatif dan lebih menarik. Maka diperlukan solusi yang mampu meningkatkan proses belajar mengajar yaitu blended learning bisa menjadi rekomendasi dalam upaya perbaikan pembelajaran, karena metode blended learning sesuai diterapkan dalam kondisi covid-19 selama pembelajaran jarak jauh.

Blended learning merupakan perkembangan metode pembelajaran yang memadukan antara metode konvensional secara tatap muka dengan sistem e-learning (Setiawan et al., 2020). Sejalan dengan itu, Uwes A. Chaeruman mengungkapkan blended learning sebagai pembelajaran yang menyatukan metode pembelajaran berbasis synchronous dan asynchronous guna mewujudkan tujuan belajar yang ingin dicapai. Proses yang terjadi dari dua desain pembelajaran berbeda, yakni peserta didik belajar dan mengerjakan kegiatan pembelajaran pada waktu yang sama dengan desain pembelajaran asynchronous. Sebaliknya, desain pembelajaran synchronous biasanya peserta didik melakukan aktivitas pembelajaran dalam waktu yang bersamaan, namun dilakukan pada kurun waktu tertentu (Chaeruman, 2013).

Kelebihan blended learning ini adalah pembelajaran dapat berlangsung secara fleksibel karena pembelajaran ini berlangsung secara online dan tatap muka, sehingga aktivitas belajar dapat bervariatif, mampu meningkatkan aksesbilitas serta dapat berjalan lebih efektif dan efisien (Hidayat \& Andira, 2019). Blended learning terbukti berhasil meningkatkan kualitas hasil belajar. Meta analisis terhadap keefektifan blended learning periode publikasi tahun 1996-2003 dan 2004-2008 yang dilakukan oleh Means menyebutkan siswa dalam pembelajaran online mencapai rata-rata hasil belajar yang lebih baik dari pada siswa yang melakukan aktivitas belajar secara tatap muka (Means et al., 2013).

Blended learning memiliki empat ruang belajar diantaranya yaitu live synchronous (sinkron langsung), virtual synchronous (sinkron virtual), collaborative asynchronous (asinkron kolaboratif), dan self-paced asynchronous (asinkron mandiri) (Chaeruman \& Maudiarti, 2018). Pembelajaran sinkron ini berlangsung secara nyata/real di dalam kelas (Gawise et al., 2021). Namun dari keempat ruang belajar tersebut, dalam masa pandemi ini ruang belajar live synchronous (sinkron langsung) tidak bisa dilaksanakan, sehingga kegiatan belajar mengajar bisa menerapkan ketiga ruang belajar lainnya (Chaeruman, 2020). Karena hal tersebut, kegiatan pembelajaran sinkron selama PJJ hanya dilakukan dengan sinkron virtual, sehingga dalam penerapan blended learning selama pembelajaran jarak jauh, guru bisa merencanakan pembelajaran dengan menggunakan media teleconference sebagai pengganti kegiatan tatap muka. Adapun media pembelajaran sinkron virtual yang bisa dijadikan pengganti kegiatan belajar dengan tatap muka di sekolah yaitu dengan penggunaan google meet. Penggunaan video conference dapat dijadikan preferensi agar komunikasi dan interaksi tetap terjalin antara pengajar dengan siswa dalam pembelajaran jarak jauh.

Begitupun dalam pelaksanakan pembelajaran secara blended memerlukan penggunaan Learning Management System (LMS). Pembelajaran secara blended perlu didukung suatu aplikasi LMS yang dapat digunakan untuk mengelola pembelajaran online. Salah satunya yaitu aplikasi google classroom yang dapat diakses melalui android maupun laptop, mudah dalam penggunaannya, dan aplikasi yang cukup ringan dijangkau oleh peserta didik kendatipun dengan berbagai keterbatasan jaringan internet dari rumah. Layanan google classroom bisa dijadikan alternatif sebagai media pembelajaran asinkronus selama PJJ untuk melengkapi proses belajar dengan sinkron virtual sehingga kualitas pembelajaran lebih optimal.

Penelitian Arlena et al. (2018) dan Elmeida \& Pranajaya (2017) menyebutkan bahwa blended learning berpengaruh signifikan terhadap motivasi belajar, artinya blended learning yang diterapkan dengan baik maka menjadikan semakin tinggi motivasi belajar. Selanjutnya penelitian Khoiroh et al. (2017) dan Nande \& Irman (2021) menjelaskan bahwa siswa yang mendapatkan pembelajaran blended learning hasil belajarnya lebih 
meningkat. Didukung pula penelitian lain yang membuktikan keefektifan blended learning dalam meningkatkan motivasi dan hasil belajar siswa diantaranya penelitian Anggraini et al. (2020), Manggabarani et al. (2016), dan Kholifah \& Buditjahjanto (2016). Dari penelitian diperoleh hasil yang menyebutkan keunggulan yang dimiliki blended learning mampu mengoptimalkan kemampuan dan kapabilitas siswa, serta dinilai cocok untuk diterapkan dalam kondisi pandemi saat ini dimana kegiatan belajar berlangsung secara daring sehingga bisa mengkolaborasikan metode online dengan tatap muka.

Pada penelitian sebelumnya yang telah meneliti mengenai blended learning, proses pembelajaran diterapkan secara tatap muka langsung di kelas dan hasilnya memberikan pengaruh positif terhadap pembelajaran di kelas. Namun dengan kondisi pandemi saat ini kegiatan belajar dilakukan secara daring menjadikan pembelajaran tatap muka di kelas diganti secara virtual dengan bantuan video conference google meet, sehingga penelitian ini ingin menganalisa apakah ketika blended learning diterapkan secara tatap muka virtual juga bisa memberikan pengaruh positif seperti penelitian sebelumnya. Mengingat kualitas pembelajaran harus tetap diperhatikan meskipun dalam kondisi pandemi seperti saat ini, sehingga pemanfaatan teknologi informasi dan komunikasi bisa menjadi solusi untuk menumbuhkan semangat peserta didik dalam belajar dengan diterapkannya blended learning. Berdasarkan keuntungan yang telah dipaparkan, blended learning efektif untuk bisa diterapkan di era new normal saat ini (Utari et al., 2020).

Penelitian ini dapat membantu guru untuk lebih mempersiapkan strategi belajar yang lebih matang dan terencana selama pembelajaran jarak jauh sehingga suasana belajar dan motivasi siswa bisa meningkat dan dapat diperoleh hasil belajar yang maksimal jika guru bisa menerapkan dengan sebaik mungkin. Selain itu peserta didik akan memperoleh kepuasan dalam belajar serta lebih mudah untuk memahami penjelasan materi dikarenakan bisa berinteraksi langsung dengan guru dan peserta didik lain dalam ruang virtual. Oleh karenanya, peneliti memberikan solusi dengan diterapkannya blended learning berbasis sinkron virtual berbantuan google meet dan asinkron berbantuan google classroom dalam kegiatan pembelajaran ekonomi yang mana diharapkan mampu meningkatkan motivasi dan hasil belajar peserta didik dalam pembelajaran jarak jauh.

\section{METODE}

Pelaksanaan penelitian ini menggunakan jenis penelitian kuasi eksperimen atau eksperimen semu dengan pendekatan kuantitatif. Bentuk desain penelitian dalam penelitian ini yaitu Post-test Only Control Group Design yang mana antara kelompok eksperimen maupun kelompok kontrol dibandingkan dengan mendapatkan perbedaan perlakuan. Kelas eksperimen diterapkan perlakuan penerapan blended learning sedangkan kelas kontrol tidak mendapatkan perlakuan. Penelitian dilaksanakan di SMA Negeri 1 Puri Mojokerto. Peneliti menentukan 30 siswa kelas XI IPS 3 sebagai sampel untuk kelompok eksperimen dan sebanyak 30 siswa kelas XI IPS 2 menjadi sampel kelompok kontrol. Sehingga keseluruhan jumlah sampel adalah 60 siswa.

Penelitian ini menggunakan teknik pengumpulan data dengan wawancara, observasi, dan dokumentasi. Untuk rancangan instrumen penelitian yaitu menggunakan kuesioner motivasi dan tes hasil belajar (posttest) yang diberikan diakhir pertemuan setelah dilakukan penelitian pada kelas ekperimen dan kelas kontrol. Instrumen motivasi belajar dalam penelitian ini menggunakan kuesioner MSLQ (Motivated Strategies for Learning Questionnaire) yang terdiri dari 28 item pernyataan diadaptasi dari Pintrich et al. (1991) yang telah dimodifikasi oleh peneliti, sedangkan untuk instumen tes hasil belajar diukur dengan 30 soal pilihan ganda materi inflasi, kebijakan moneter, dan kebijakan fiskal. Data kuesioner motivasi dan hasil tes belajar yang diperoleh merupakan data kuantitatif. Data yang diperoleh dari penelitian dianalisis menggunakan analisis statistik deskriptif dan inferensial. Langkah-langkah yang ditempuh dalam pengolahan data statistik 
inferensial yaitu uji normalitas, uji homogenitas, dan uji hipotesis dengan melakukan uji indpendent sample ttest dengan bantuan program SPSS Statistics 26.

\section{HASIL DAN PEMBAHASAN}

\section{Analisis Motivasi Belajar}

Berdasarkan data hasil kuesioner variabel motivasi belajar peserta didik yang diberikan pada kelas eksperimen dan kelas kontrol, jumlah item pernyataan kuesioner sebelum diuji validitas dan reliabilitas sebanyak 31 item pernyataan dan menjadi 28 item pernyataan setelah diuji validitas dan reliabilitasnya. Hasil statistik deskriptif motivasi belajar kelas XI IPS 3 menunjukkan bahwa skor variabel motivasi belajar pada kelas eksperimen berada antara 82 sampai dengan 109, memiliki nilai rata-rata (mean) sebesar 94,57, median 95,00, modus 85, varians 64,806, dan standar deviasi 8,050. Sedangkan hasil statistik deskriptif motivasi belajar kelas XI IPS 2 menunjukkan bahwa skor variabel motivasi belajar pada kelas kontrol berada antara 75 sampai dengan 101, adapun nilai rata-rata (mean) sebesar 88,00, median 87,00, modus 85 , varians 55,793, dan standar deviasi 7,469.

Berikut ditunjukkan pengelompokan skor motivasi belajar siswa dari hasil penyebaran kuesioner setelah kedua kelas diberikan perbedaan perlakuan sebagai berikut:

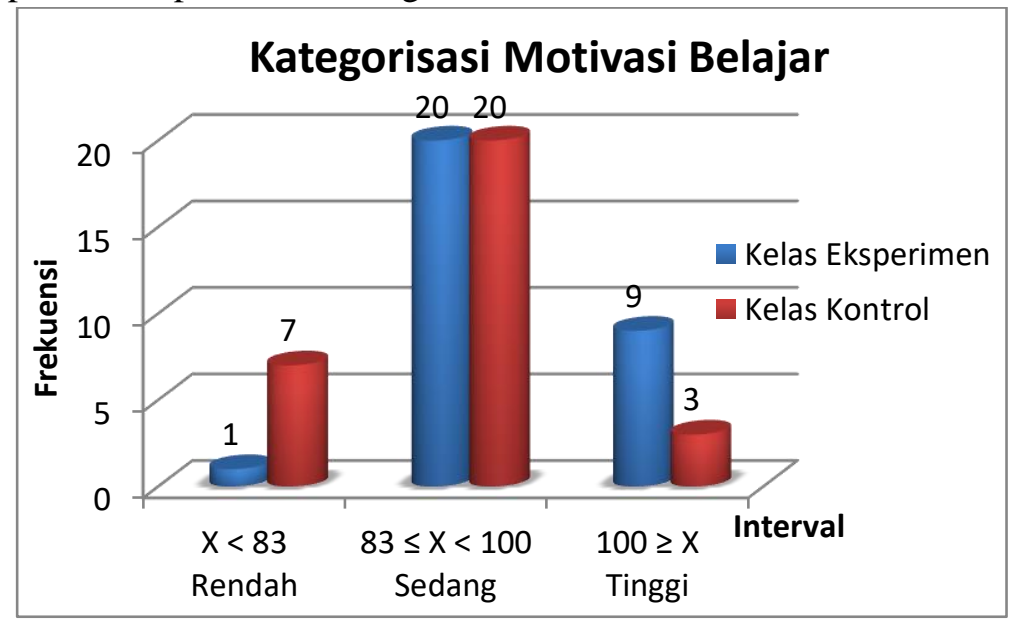

Gambar 1. Histogram Kategorisasi Motivasi Belajar

Mengacu pada pengelompokan skor motivasi belajar di atas, kelas eksperimen yang mendapatkan pembelajaran blended learning dalam materi inflasi, kebijakan moneter, dan kebijakan fiskal yang kemudian diberikan kuesioner, adapun skor motivasi belajar yang diperoleh peserta didik diantaranya untuk 9 siswa masuk kategori motivasi tinggi, 20 siswa tergolong dalam motivasi sedang, dan untuk kategori rendah terdapat 1 siswa. Sementara itu, pada kelas kontrol yang tidak mendapatkan pembelajaran dengan blended learning diperoleh skor motivasi belajar setelah diberikan kuesioner yaitu terdapat 3 siswa tergolong dalam kategori tinggi, 20 siswa yang motivasi belajarnya sedang, dan 7 siswa termasuk motivasi belajarnya rendah.

\section{Analisis Hasil Belajar}

Berdasarkan hasil statistik deskriptif untuk variabel hasil belajar yang diukur dengan soal posttest sebanyak 30 soal pilihan ganda menunjukkan bahwa pada kelas eksperimen skor maksimum hasil belajar ekonomi setelah diberikan perlakuan dengan penerapan blended learning adalah 93 dan skor minimumnya ialah 43. Untuk rata-rata nilainya (mean) adalah 71,63. Adapun standar deviasi yang diproleh yaitu sebesar 12,899. Begitu pula untuk nilai varians yang diperoleh sebesar 166,378 dan koefisien variasi sebesar 18,008\%.

Sedangkan untuk hasil deskriptif pada kelas kontrol, menunjukkan bahwa skor maksimum hasil belajar ekonomi peserta didik setelah diterapkan pembelajaran jarak jauh melalui asinkron berbantuan google 
classroom adalah 83 dan skor minimumnya yaitu 27. Rata-rata nilai (mean) yang diperoleh adalah 55,60 dengan standar deviasi 16,119. Adapun varians yang diperoleh yaitu sebesar 259,834 serta koefisien variasi sebesar 28,991\%. Pada koefisien variasi, jika nilai koefisien variasi yang diperoleh dari data semakin kecil itu artinya semakin merata pemberian perlakuan kepada anggota sampel dalam penelitian. Berdasarkan deskripsi data tersebut, maka dapat diketahui bahwa persebaran hasil belajar siswa pada kelas eksperimen lebih merata dikarenakan nilai koefisien variasinya lebih kecil.

Untuk menentukan kategorisasi dari nilai posttest, maka ditunjukkan distribusi kategori skor hasil belajar ekonomi (posttest) setelah kedua kelas diberikan perbedaan perlakuan sebagai berikut:

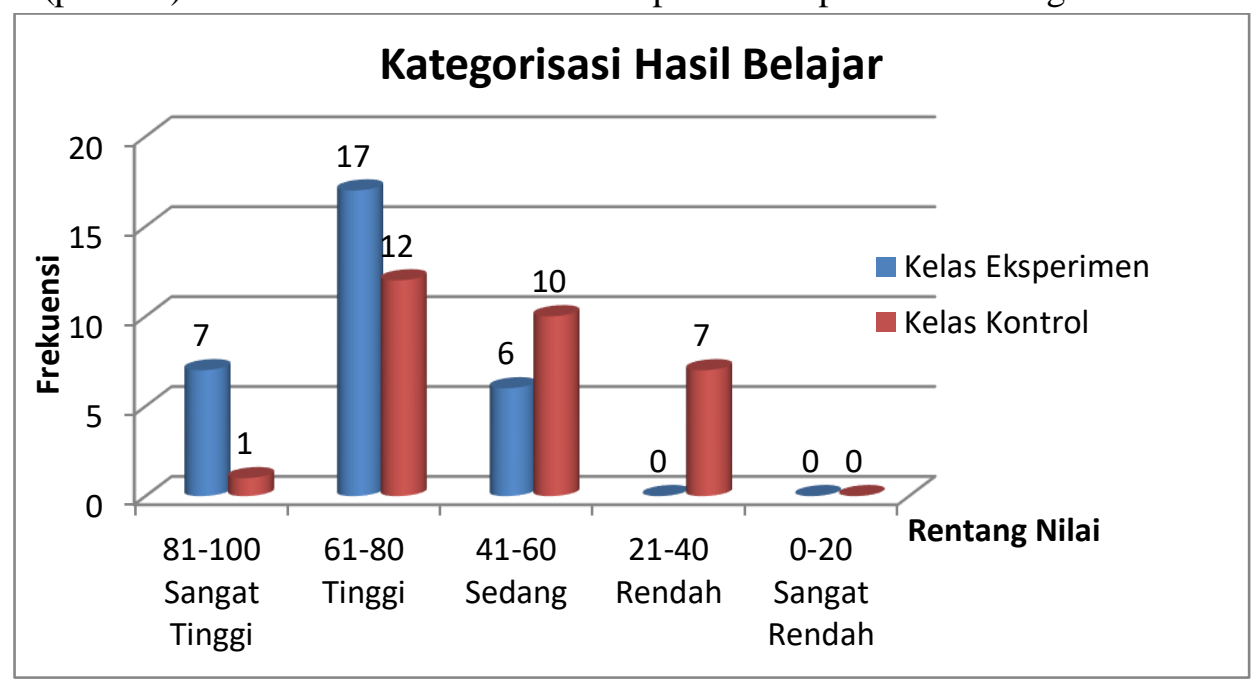

Gambar 2. Histogram Kategorisasi Posttest Peserta Didik

Mengacu pada pengelompokan nilai posttest di atas, kelas eksperimen yang mendapatkan pembelajaran blended learning dan diberikan soal posttest tentang materi inflasi, kebijakan moneter, dan fiskal, memperoleh hasil belajar sebagai berikut terdapat 6 peserta didik tergolong kategori sedang dengan persentase 20\%, 17 peserta didik mendapat kategori hasil belajar tinggi memiliki persentase $56,67 \%$, serta untuk kategori sangat tinggi ada 7 peserta didik dengan persentase $23,33 \%$. Sementara itu, peserta didik pada kelas eksperimen tidak ada yang mendapat kategori rendah dan sangat rendah. Sedangkan setelah diberikan posttest pada kelas kontrol yang tidak mendapatkan penerapan pembelajaran menggunakan blended learning, nilai posttest yang diperoleh diantaranya terdapat 7 peserta didik tergolong kategori rendah memiliki persentase $23,33 \%$, ada 10 peserta didik mendapat kategori hasil belajar sedang dengan persentase 33,33\%, dan 12 peserta didik ada pada kategori tinggi dengan persentase $40 \%$ serta 3,33\% yang mendapat kategori sangat tinggi dengan 1 peserta didik. Sementara itu, untuk kategori hasil belajar sangat rendah tidak terdapat siswa yang masuk kategori tersebut pada kelas kontrol.

\section{Hasil Pengujian Hipotesis Motivasi Belajar}

Hasil pengujian dengan independent sample-t test pada variabel motivasi belajar ekonomi dapat diketahui melalui tabel berikut:

Tabel 1. Hasil Uji Independent Sample-T Test Motivasi Belajar

\begin{tabular}{|c|c|c|}
\hline \multicolumn{3}{|c|}{ Motivasi Belajar } \\
\hline & \multicolumn{2}{|c|}{ Equal variances assumed } \\
\hline \multirow{2}{*}{$\begin{array}{c}\text { t-test for } \\
\text { Equality of } \\
\text { Means }\end{array}$} & $\mathrm{T}$ & 3,275 \\
\cline { 2 - 3 } & $\mathrm{Df}$ & 58 \\
\cline { 2 - 3 } & sig. (2-tailed) & 0,002 \\
\hline
\end{tabular}

Sumber : Data Olahan Hasil Penelitian 
Berdasarkan hasil yang diperoleh pada tabel output di atas dapat dilihat bahwa nilai sig. (2-tailed) adalah $0,002<0,05$. Dari keterangan tersebut maka dinyatakan $\mathrm{H}_{0}$ ditolak dan $\mathrm{H}_{1}$ diterima, hal ini berarti terdapat perbedaan motivasi belajar peserta didik yang signifikan antara kelas eksperimen dengan kelas kontrol. Dengan demikian, dugaan bahwa terdapat perbedaan motivasi belajar antara kelas yang belajar dengan penerapan blended learning dan kelas yang tidak mendapatkan blended learning selama pembelajaran jarak jauh pada mata pelajaran ekonomi adalah benar dengan didukung oleh data hasil penelitian pada nilai signifikansi $0,002<0,05$.

Berdasarkan fakta di lapangan, perbedaan tersebut bisa terjadi dikarenakan peserta didik pada kelas eksperimen yang mendapatkan pembelajaran blended learning merasa senang dan lebih aktif dalam aktivitas belajar, dimana peserta didik membutuhkan penjelasan materi secara langsung oleh guru agar lebih mudah menyerap materi pelajaran ekonomi dengan maksimal. Melalui blended, peserta didik juga tetap mendapatkan pembelajaran tatap muka virtual berbantuan google meet karena blended learning memiliki fleksibilitas waktu dan proses pembelajaran berjalan efektif dengan tanya jawab penjelasan materi maupun diskusi bersama, sehingga kepuasan dan kualitas dalam belajar terpenuhi serta tujuan tercapai secara optimal. Oleh karenanya, peserta didik merasa termotivasi untuk belajar dikarenakan bisa langsung berinteraksi dan bisa aktif berpartisipasi dalam proses pembelajaran baik secara tatap muka virtual maupun secara pembelajaran asinkron.

Perbedaan motivasi belajar pada kelas kontrol dikarenakan guru berperan sebagai pusat pembelajaran sehingga dalam kegiatan pembelajaran membuat peserta didik cenderung pasif. Peserta didik juga cenderung merasa jenuh, tidak bersemangat, dan kurang memperhatikan pada saat proses pembelajaran dikarenakan guru hanya mengirim materi dan tugas melalui google classroom tanpa ada penjelasan lebih detail. Peserta didik cenderung merasa bosan dan tidak bersemangat karena apa yang diperoleh peserta didik hanya berasal dari buku-buku pelajaran dan materi yang dikirim oleh guru yang mana mereka pelajari secara mandiri tanpa ada penjelasan materi dari guru.

Blended learning berpeluang menggeser paradigma pembelajaran yang hanya di kelas menuju paradigma baru yakni belajar dimana pun dan kapan pun itu. Pembelajaran ini menjadikan adanya perpaduan antar berbagai media, sumber belajar, strategi maupun berbagai suasana belajar yang bermakna, serta bisa berpeluang meningkatkan interaksi antara pendidik dengan siswa, siswa dengan siswa, siswa/ pendidik dengan konten, siswa/ pendidik dengan sumber belajar lainnya (Wijaya et al., 2016). Sejalan dengan hal tersebut, kelas eksperimen yang memperoleh penerapan blended learning menjadikan adanya peningkatan motivasi dan semangat belajar karena terdapat interaksi selama proses pembelajaran. Hermawanto dkk juga mengungkapkan bahwa keunggulan dari penerapan blended learning ialah peserta didik dapat memperoleh lebih banyak informasi dan wawasan ketika belajar secara online dari banyak sumber belajar seperti pengungkapan pendapat, tanya jawab, berdiskusi, belajar melalui video maupun bentuk gambar. (Hermawanto et al., 2013).

Hasil penelitian ini sejalan dengan penelitian Arlena et al. (2018) diperoleh hasil bahwa terdapat pengaruh positif antara blended learning terhadap motivasi belajar mahasiswa, hal ini berarti blended learning berpengaruh signifikan terhadap motivasi belajar mahasiswa. Adapun diperkuat pula oleh penelitian Elmeida \& Pranajaya (2017) yang mengungkapkan bahwa dengan penerapan blended learning mampu memberikan pengaruh yang lebih besar dibuktikan dari hasil pretest dan posttest menghasilkan motivasi belajar mahasiswa meningkat menjadi tinggi. 
861 Apakah Penerapan Blanded Learning Dapat Meningkatkan Motivasi dan Hasil Belajar Siswa dalam

Pembelajaran Jarak Jauh? - Lidya Angie Widyasari, Mohamad Arief Rafsanjani

DOI: https://doi.org/10.31004/edukatif.v3i3.453

\section{Hasil Pengujian Hipotesis Hasil Belajar Ekonomi}

Hasil uji independent sample-t test data mengenai hasil belajar ekonomi peserta didik dapat diketahui pada tabel berikut:

Tabel 2. Hasil Uji Independent Sample-T Test Hasil Belajar

\begin{tabular}{|c|c|c|}
\hline \multicolumn{3}{|c|}{ Hasil Belajar } \\
\hline & \multicolumn{2}{|c|}{ Equal variances assumed } \\
\hline \multirow{2}{*}{$\begin{array}{c}\text { t-test for } \\
\text { Equality of } \\
\text { Means }\end{array}$} & $\mathrm{T}$ & 4,254 \\
\cline { 2 - 3 } & $\mathrm{Df}$ & 58 \\
\cline { 2 - 3 } & sig. (2-tailed) & 0,000 \\
\hline
\end{tabular}

Sumber : Data Olahan Hasil Penelitian

Berdasarkan hasil yang diperoleh pada tabel output di atas dapat dilihat bahwa nilai sig. (2-tailed) adalah $0,000<0,05$. Mengacu pada keterangan tersebut maka dinyatakan $\mathrm{H}_{0}$ ditolak dan $\mathrm{H}_{1}$ diterima, hal ini berarti terdapat perbedaan hasil belajar peserta didik yang signifikan antara kelas eksperimen dengan kelas kontrol. Dengan demikian, dugaan bahwa terdapat perbedaan hasil belajar antara kelas yang belajar dengan penerapan blended learning dan kelas yang tidak mendapatkan blended learning selama pembelajaran jarak jauh pada mata pelajaran ekonomi adalah benar dengan didukung oleh data hasil penelitian pada nilai signifikansi $0,000<0,05$.

Pada kelas eksperimen merasakan suasana belajar yang baru dengan blended learning dikarenakan dalam penerapannya peserta didik diberikan penyajian materi dengan mengaitkan dengan fenomena/kejadian dalam bentuk gambar maupun video sehingga materi pembelajaran tidak hanya bersumber dari buku yang cenderung membosankan. Hal ini bisa menumbuhkan rasa ketertarikan dan penasaran pada peserta didik untuk mengikuti proses pembelajaran. Fenomena/kejadian yang disajikan merupakan fenomena yang ada di sekitar peserta didik, sehingga menciptakan aktivitas belajar ekonomi tampak lebih nyata dan bermakna bagi peserta didik. Karena proses pembelajaran yang tidak ideal cenderung akan membingungkan penerimanya dan minat untuk belajar bisa berkurang. Perbedaan peningkatan hasil belajar ekonomi ini disebabkan dari motivasi dan antusias belajar pada kelas eksperimen yang lebih tinggi untuk memperhatikan pembelajaran dan menanyakan materi maupun soal yang kurang dipahami akibat meningkatnya semangat dan partisipasi keaktifan peserta didik selama pembelajaran dengan blended learning. Sedangkan suasana belajar pada kelas kontrol cenderung lebih pasif dikarenakan kurang adanya interaksi dengan guru secara langsung. Dalam hal ini dapat dikatakan bahwa siswa merasa antusias belajar dan mudah menerima materi pelajaran dengan baik jika suasana dan aktivitas belajar yang diciptakan lebih menyenangkan.

Peserta didik dapat mengembangkan pengalaman belajar, kemandirian, dan fleksibilitas melalui pembelajaran dengan blended learning, selain itu guru juga memungkinkan untuk memperbanyak waktu yang digunakan sebagai fasilitator pembelajaran (DreamBox, 2013). Blended Learning dapat memberikan banyak kesempatan untuk mendalami materi pelajaran melalui pemanfaatan sumber belajar pada pembelajaran online secara mandiri (Nurhayati \& Apriani, 2020). Nurhayati dan Apriani juga mengungkapkan bahwa pembelajaran online dapat dikatakan sebagai waktu belajar tambahan bagi siswa kerena sudah tersedia informasi sebelum aktivitas belajar dimulai, sehingga bisa lebih efisien untuk siswa memahami materi secara mandiri, berdiskusi, dan mengerjakan tugas/latihan soal. Hal ini secara tidak langsung dapat meningkatkan pemahaman siswa akan materi pelajaran, dengan begitu maka hasil belajar yang diperoleh juga dapat meningkat.

Hasil penelitian ini sejalan dengan penelitian Mandang \& Tulandi (2020) yang menyebutkan terdapat perbedaan hasil belajar siswa dengan diterapkannya pembelajaran blended learning. Adapun penelitian lain yang dilakukan oleh Aprilia (2015) diperoleh hasil bahwa ada peningkatan hasil belajar setelah penerapan blended learning dan persentase ketuntasan belajar kognitif pun meningkat. Keberhasilan dalam mencapai 
ketuntasan belajar oleh sebagian siswa tersebut menunjukkan bahwa tingkat pemahaman dan penguasaan terhadap materi yang diajar akan lebih meningkat setelah diberikan penerapan blended learning.

Hasil yang diperoleh dari motivasi dan hasil belajar menunjukkan bahwa pembelajaran yang menggunakan blended learning dinilai mampu mendorong motivasi belajar dan peningkatan hasil belajar peserta didik yang signifikan. Hal tersebut diharapkan mampu memberikan strategi baru dalam belajar dengan penerapan blended learning berbasis sinkron asinkron untuk bisa diterapkan dalam pembelajaran jarak jauh oleh para guru, agar lebih maksimal dalam pemberian kegiatan belajar mengajar dengan harapan mampu meningkatkan motivasi dan hasil belajar peserta didik.

Di samping itu terdapat keterbatasan pada penelitian ini yaitu penggunaan media google meet dan google classroom dapat diakses menggunakan laptop/computer dan smartphone android, sehingga peserta didik yang tidak memiliki laptop/computer dan android tidak mendukung pembelajaran daring. Selain itu, kendala lain yang muncul yakni pada kuota dan koneksi internet dikarenakan pembelajaran ini menghabiskan banyak kuota internet serta koneksi jaringan yang baik, sehingga dibutuhkan kuota dan koneksi internet yang memadai untuk dapat mengakses internet guna mendukung berlangsungnya proses pembelajaran.

\section{KESIMPULAN}

Mengacu pada analisis penelitian yang telah dideskripsikan mengenai motivasi dan hasil belajar melalui penerapan blended learning dalam pembelajaran jarak jauh dapat diperoleh rata-rata skor motivasi belajar kelas eksperimen lebih tinggi daripada kelas kontrol. Begitu pula untuk rata-rata nilai hasil belajar, kelas eksperimen mencapai rata-rata lebih tinggi daripada kelas kontrol. Berdasarkan uji hipotesis diperoleh hasil penelitian bahwa (1) terdapat perbedaan motivasi belajar yang signifikan antara kelas eksperimen dan kelas kontrol, (2) terdapat perbedaan hasil belajar ekonomi yang signifikan antara kelas eksperimen dan kelas kontrol. Dengan demikian dapat ditarik kesimpulan bahwa motivasi dan hasil belajar ekonomi peserta didik dapat mengalami peningkatan dengan diterapkannya blended learning berbasis sinkron dan asinkron dalam pembelajaran jarak jauh. Motivasi dan semangat belajar dalam diri siswa perlu untuk lebih ditumbuhkan dan ditingkatkan selama pembelajaran jarak jauh sehingga mampu meningkatkan penguasaan materi ekonomi dan bisa memperoleh hasil belajar lebih optimal. Guru bisa memanfaatkan penggunaan pembelajaran blended learning untuk diterapkan selama pembelajaran jarak jauh.

\section{UCAPAN TERIMA KASIH}

Jika perlu berterima kasih kepada pihak tertentu, misalnya sponsor penelitian, nyatakan dengan jelas dan singkat, hindari pernyataan terima kasih yang berbunga-bunga.

\section{DAFTAR PUSTAKA}

Anggraini, N., Suana, W., \& Sesunan, F. (2020). Pengaruh Penerapan Blended Learning pada Materi Hukum Newton Tentang Gerak Terhadap Motivasi Belajar dan Kemampuan Pemecahan Masalah. Jurnal Ilmu Pendidikan, 16(1), 22-36.

Aprilia, R. (2015). Penerapan Blended Learning untuk Meningkatkan Hasil Belajar Siswa. Jurnal Kajian Pendidikan Teknik Bangunan, 1(1).

Arlena, A., Effendi, Z. M., \& Sofya, R. (2018). PENGARUH BLENDED LEARNING TERHADAP MOTIVASI BELAJAR MAHASISWA PADA MATA KULIAH METODOLOGI PENELITIAN JURUSAN PENDIDIKAN EKONOMI FE UNP. EcoGen, 1(1), 28-35.

Chaeruman, U. A. (2013). MERANCANG MODEL BLENDED LEARNING. Jurnal Teknodik, 17(4), 399- 
863 Apakah Penerapan Blanded Learning Dapat Meningkatkan Motivasi dan Hasil Belajar Siswa dalam Pembelajaran Jarak Jauh? - Lidya Angie Widyasari, Mohamad Arief Rafsanjani

DOI: https://doi.org/10.31004/edukatif.v3i3.453

409.

Chaeruman, U. A. (2020). Tips Implementasi Flipped Learning. Materi Disajikan Dalam Webinar APSTPI 2020.

Chaeruman, U. A., \& Maudiarti, S. (2018). Quadrant of Blended Learning: a Proposed Conceptual Model for Designing Effective Blended Learning. Jurnal Pembelajaran Inovatif, 1(1), 1-5. https://doi.org/10.21009/JPI.011.01 Article

DreamBox. (2013). 6 Models of Blended Learning.

Elmeida, I. F., \& Pranajaya, R. (2017). PENGARUH METODE PEMBELAJARAN BLENDED LEARNING TERHADAP MOTIVASI BELAJAR MAHASISWA KEBIDANAN POLTEKKES TANJUNGKARANG. Jurnal Keperawatan, XIII(1), 35-41.

Gawise, Tarno, \& Lestari, A. A. (2021). Efektifitas Pembelajaran Model Flipped Classroom masa Pandemi Covid-19 terhadap Hasil Belajar di Sekolah Dasar Abstrak. Edukatif: Jurnal Ilmu Pendidikan, 3(1), 246-254. https://doi.org/https://doi.org/10.31004/edukatif.v3i1.328

Hermawanto, Kusairi, S., \& Wartono. (2013). Pengaruh Blended Learning terhadap Penguasaan Konsep dan Penalaran Fisika Peserta Didik Kelas X. Jurnal Pendidikan Fisika Indonesia, 9(57), 67-76.

Hidayat, M. yusuf, \& Andira, A. (2019). PENGARUH MODEL PEMBELAJARAN HYBRID LEARNING BERBANTUAN MEDIA SCHOOLOGY TERHADAP HASIL BELAJAR PESERTA DIDIK KELAS XI MIA MAN PANGKEP. Jurnal Pendidikan Fisika, 7(2), 140-148. http://journal.uinalauddin.ac.id/indeks.php/PendidikanFisika

Kemendikbud. (2020). Surat Edaran Kemendikbud Nomor 4 Tahun 2020. https://jdih.kemdikbud.go.id/arsip/SE Menteri Nomor 4 Tahun 2020 cap.pdf

Khoiroh, N., Munoto, \& Anifah, L. (2017). PENGARUH MODEL PEMBELAJARAN BLENDED LEARNING DAN MOTIVASI BELAJAR TERHADAP HASIL BELAJAR SISWA. Jurnal Penelitian Ilmu Pendidikan, 10(2), 97-110.

Kholifah, S. N., \& Buditjahjanto, I. G. P. A. (2016). PENGARUH MODEL PEMBELAJARAN BLENDED LEARNING TERHADAP HASIL BELAJAR DAN MOTIVASI BELAJAR SISWA KELAS XI TEI PADA MATA PELAJARAN KOMUNIKASI DATA DAN INTERFACE DI SMK NEGERI 1 JETIS MOJOKERTO. Jurnal Pendidikan Teknik Elektro, 5(3), 975-982.

Mandang, T., \& Tulandi, D. A. (2020). PENINGKATKAN HASIL BELAJAR SISWA MELALUI PEMBELAJARAN BLENDED LEARNING MATERI LISTRIK DINAMIS. JURNAL PENDIDIKAN FISIKA UNIMA, 1(1), 28-33.

Manggabarani, A. F., Sugiarti, \& Masri, M. (2016). Pengaruh Model Pembelajaran Blended Learning Terhadap Motivasi dan Hasil Belajar Siswa Kelas X SMA Negeri 1 Pitumpanua Kab . Wajo (Studi Pada Materi Pokok Sistem Periodik Unsur). Jurnal Chemica, 17(2), 83-93.

Maulida, U. (2020). KONSEP BLENDED LEARNING BERBASIS EDMODO DI ERA NEW NORMAL. 2, 121-136.

Means, B., Toyama, Y., Murphy, R., \& Baki, M. (2013). The Effectiveness of Online and Blended Learning: A Meta-Analysis of the Empirical Literature. Teachers College Record, 115(030303), 1-47.

Nande, M., \& Irman, W. A. (2021). Penerapan Model Pembelajaran Blanded Learning dalam Meningkatkan Hasil Belajar Siswa Sekolah Menengah Kejuruan. Edukatif: Jurnal Ilmu Pendidikan, 3(1), 180-187. https://doi.org/https://doi.org/10.31004/edukatif.v3i1.240

Nurhayati, \& Apriani, W. (2020). EFEKTIVITAS BLENDED LEARNING BERBANTUAN SPSS TERHADAP TINGKAT PEMAHAMAN MAHASISWA PADA MATA KULIAH STATISTIK. Jurnal Pendidikan Matematika Dan Sains, 1(1), 12-16.

Pintrich, P. R., Smith, D. A. F., Garcia, T., \& McKeachie, W. J. (1991). A Manual for the Use of the 
864 Apakah Penerapan Blanded Learning Dapat Meningkatkan Motivasi dan Hasil Belajar Siswa dalam Pembelajaran Jarak Jauh? - Lidya Angie Widyasari, Mohamad Arief Rafsanjani

DOI: https://doi.org/10.31004/edukatif.v3i3.453

Motivated Strategies for Learning Questionnaire (MSLQ). National Center for Research to Improve Postsecondary Teaching and Learning, Ann Arbor, MI.

Setiawan, D., Irawati, M. H., Indriwati, S. E., Saptasari, M., Fachrunnisa, R., \& Mardiyanti, L. (2020). PENGARUH MODEL PEMBELAJARAN BERBASIS MASALAH DENGAN METODE HYBRID LEARNING TERHADAP KETERAMPILAN KOMUNIKASI MAHASISWA PADA MATAKULIAH PENGEMBANGAN PROFESI GURU. Jurnal Pendidikan Biologi, 11(2), 77-82. https://doi.org/http://dx.doi.org/10.17977/um052v11i2p70-76

Utari, W., Hikmawati, V. Y., \& Gaffar, A. A. (2020). BLENDED LEARNING: STRATEGI PEMBELAJARAN ALTERNATIF DI ERA NEW NORMAL. Seminar Nasional Pendidikan. FKIP UNMA, 262-269.

Wijaya, I. M. ., Suweken, G., \& Mertasari, N. M. . (2016). PENGARUH PENERAPAN MODEL PEMBELAJARAN BLENDED LEARNING TERHADAP MOTIVASI BERPRESTASI DAN PRESTASI BELAJAR MATEMATIKA SISWA SMA NEGERI 1 SINGARAJA. Jurnal Wahana Matematika Dan Sains, 10(2), 36-47. 